\title{
IAMJ
}

INTERNATIONAL

AYURVEDIC

MEDICAL JOURNAL

\section{AN AYURVEDIC REVIEW ON ASHTA AHARA VIDHI VISHESH AYATANA}

\author{
Namrata Sahu', Vinay Bhardwaj ${ }^{2}$, Gitanjali Sasmal ${ }^{3}$ \\ ${ }^{1}$ Post Graduate Scholar, ${ }^{2}$ Lecturer, ${ }^{3}$ Reader \& HOD. \\ P.G. Department of Kriya Sharira, Shri NPA Govt Ayurved College, Raipur, C.G., India
}

Corresponding Author: namratasahu601@gmail.com

\section{https://doi.org/10.46607/iamj3609092021}

(Published Online: September 2021)

Open Access

(C) International Ayurvedic Medical Journal, India 2021

Article Received: 24/08//2021 - Peer Reviewed: 03/09/2021 - Accepted for Publication: 04/09/2021

\section{Check for updates}

\section{ABSTRACT}

Health is that the state of physical, mental, social, and spiritual well-being. It's dependent upon food and their proper food preparation method. The Prayojana of Ayurveda is to guard the health of the healthy and to cure disorders within the diseased condition. As Acharyas had described that Ahara, Nidra and Brahmacarya are Triupstambha, which support the body itself. Here Ahara has been placed first, which shows that it's most vital to take care of and sustain life. Ayurveda places a special predominance on Ahara and the right way of eating food. For the tactic of taking food, Acharya Charak has defined Ashta Ahara vidhivisheshayatana in a very systematic and scientific manner. It gives basic dietary guidelines for choosing appropriate food, quality and quantity of food, a combination of food and cooking method etc. Proper knowledge of this Ahar Vidhi Visheshayatana will help in reducing diseases and help for a proper healthy diet.

Keywords: Health, Triupastambha, Ahara, Ashta ahara vidhi visheshayatana.

\section{INTRODUCTION}

Ahara is one of the most important factors of life. Ahara is the main source of strength, complexion, and vitality. Wholesome food is one of the causes of the growth and development of living beings, while unwholesome food produces diseases. Food material is required by the body for heat and energy, tissue 
growth and the compensation of the decay of the tissues. ${ }^{1}$ Food causes immediate nourishment, strength, and support to the body. It increases the expectancy of life, brilliance, enthusiasm, memory, Ojas and digestive capacity. ${ }^{2}$ Ayurveda places special emphasis on Ahara and states that food is the vital breath of living beings (that is why) the people rush to the food, complexion, cheerfulness, good voice, long life, imagination, happiness, contentment, corpulence, strength, intellect all these depend on food. ${ }^{3}$ The body as the product of food, the disease born of food, the distinction of happiness and sorrow resulting from the distinction of wholesome and unwholesome diet. ${ }^{4}$ According to Ayurveda the reasons for all the diseases lies within our Agni i.e. digestive process. Each food we take either has Dosha Prakopaka or Dosha Shamaka action on the human body. Improper digestion (Mandagni) produces toxins (Ama) which leads to the majority of diseases. ${ }^{5}$ Health is dependent upon food and the food looks for proper methods. ${ }^{6}$ Acharya Charak has described 8 specific factors of the method of dieting in a very systematic and scientific manner which is known as Ashta Ahara Vidhi Visheshayatana. ${ }^{7}$

These are 8 specific factors of the method of dieting. ${ }^{8}$

1. Prakriti/Swabhava- Nature of food/ Quality of food.

2. Karan - Processing of food.

3. Samyoga-Combination of food.

4. Rashi-Quantity of food.

5. Desha-Habitat of food.

6. Kala-Time and seasonal variation.

7. Upayoga Samstha-Rules for dieting

8. Upayokta - The person who consumes the food.

1. Prakriti / Swabhava (Nature of food / Quality of food): Prakriti is Swabhava (nature) which is the natural existence of properties like Laghu, Guru etc. in the substance used as food and drug. As we know that everyone has got specific Sharirika and Manasika Prakriti (temperament), in the same way, according to heaviness, hotness etc each food and drug substance has also got its Prakriti. For example, Masha is Guru (heavy) and Mudga is Laghu (light), the meat of Shukra is Guru (heavy) and Ena (deer) meat is Laghu (light) in nature. ${ }^{9}$

2. Karana (Processing of Substances): Karana is also known as Samskara. It means the processing of substances which leads to alteration in the inherent properties of substances. This modification is brought about by dilution, application of heat (vaporization, distillation, and sublimation), clarification, emulsification, storing, maturing, flavouring, impregnation, preservation, and the material of receptacle. As by processing, Vrihi which is heavy to digest becomes light when transformed into Laja after frying, on the other hand, flour of roasted grains becomes heavy when processed into a cooked bolus. ${ }^{10}$

3. Samyoga (combination): Samyoga (combination) is an aggregation of two or more substances. This exhibits peculiarities that are not seen in the case of individual substances. Sometimes it is seen that the combination of diet shows the different effect from the individual effect. The combination of two or more substances results in the manifestation of special qualities, which cannot be achieved using the same article separately. The combination of 2 or more substances altogether may produce new qualities so while preparing the food it should be considered that the ingredient must be compatible with each other and should be properly mixed. For example, Honey and ghee when taken alone are wholesome to the body but when combined in equal quantity they become toxic so their combination in equal quantity is not advised. Also, milk (Shitaveerya) and fish (Ushna virya) should not be taken altogether. Though both have a sweet taste due to the contraindication in their potency they vitiate the blood and obstruct the strotas. ${ }^{11}$ the concept of Viruddha Ahara is well explained in Ayurveda which tells about the incompatible food and their harmful effect on the body. ${ }^{12}$

4. Rasi (Quantity): Rasi is the measure of the total mass and each constituent to determine the effects of the right and wrong doses. The quantity of food taken in its entirety is Sarvagrha and the 
Quantity of each of its ingredients is Parigrha. ${ }^{13}$ A person should have his diet in proper amount; it means that a person should have diet according to his digestive power (Agni). ${ }^{14}$ Rashi (quantity) consists of Sarvagraha and Parigraha which ascertain the results of the food taken in proper and improper quantity.

Sarvagraha - The account of the quantity of the entire food in totality is Sarvagraha i.e., the combined quantity of the rice, meat, pulses, condiments etc.

Parigraha - Parigraha is that one of the individual items in food. ${ }^{15}$ The Ahara in gross can be divided based on Guru and Laghu. The Guru Ahara Dravyas have Prithvi and Jala Guna predominantly; that's why they pacify the Agni if taken in large amounts so they should be taken $1 / 3$ rd or $1 / 2$ of the Kukshi. On the other hand, Laghu Ahara Dravyas predominantly have Vayu and Agni Guna, which intensify the Agni, so they are least harmful even if they are eaten to a surfeit though they should also take in proper amount. ${ }^{16}$

The absence of measure is two heads - 1. Heena Matra 2-Ati Matra

The diet which is deficient in measure (Heena Matra) is seen to result in the impairment of strength, complexion, and plumpness, in the impairment of functions of life, virility and vitality, in vitiation of the eight body elements and the incidence of the eighty kinds of Vata disorders. ${ }^{17}$

5. Desha (Habitat): Desha denotes place relating to growth as well as distribution of the substances and the suitability in respect of place. It is a geographic region. Food substances differ in quality due to differences in soil and climate. ${ }^{18}$ In Ayurveda Desha denotes both Bhoomi Desha and Dehadesha. Ahara should be taken according to Desha. The food substance grown in the same Bhoomidesh which is native Desha for the person suits him. Deshapariksha is one of the vital aspects in understanding patient regarding dietary habits of patient's probability of diseases related to the diet and accordingly treatment and Pathya aspect.
6. Kala (Time): Time is used in two senses, time in the general sense and time in the sense of stage. The since of stage is used about disease (Avastha Kala) and the general sense is used about seasonal wholesomeness (Metayage Kala), in form of day and night. Life starting from the intrauterine period till death is the entire time dynamic. People are bound to face major and minor changes in every moment of life and thereby, Doshas are also accordingly varied. In Swastha-avastha, Kala is considered as Nitayaga. In this condition, Ahara should be taken according to Dincharya and Ritucharya, which help the body function to acclimatize with the external environment. In Rugnavastha, Avasthika Kala is considered by Vyadhi Avastha. E.g., in Naveen Jwara, Langhana should be done for 7 days, but if Jwara is Jeerna Ghritapana is indicated. ${ }^{19}$ Food eaten at an appropriate time feels tasty, increase satisfaction and nutrition, gets digested easily and due to continuous/ prolong eating of food and indigestion the diseases do not develop. ${ }^{20}$

7. Upayoga- samstha (Classical Ayurveda rules of dieting): It denotes the rules for dieting. This depends on the digested food. Ahara Vidhi Visheshatayana has been described for taking food, it should be considered in the diet. Ahara should be Ushna (warm), tasty, qualitative, easily digestible. $^{21}$

8. Upyokta (The User): The user is he who makes use of food, habituation depends on him. Creating wholesomeness by habitual intake of things comes under Upyokta and known as Satmya which differs from person to person. As the Prakriti of Ahara Dravyas is a considerable factor, the Prakriti of Upyokta is also considered for the wholesomeness of diet. ${ }^{22}$ these are the factors described in our classics which are the foundation of Dietetics.

\section{DISCUSSION}

Ahara is a part of our daily routine. along with the quality, quantity, and taste of food, if we concentrate a little on the right way of taking food and the regi- 
mens related to Ahara described in Ayurveda, positive health can be achieved easily. Faulty dietary habits lead to the manifestation of different metabolic diseases. It is also observed that many diseases are arising merely due to this faulty dietary habit. In this context, the concept of Ashta Ahara Vidhi Visheshayatana is most ideal in today lifestyle. Ashta Ahara Vidhi Visheshayatana means the factors responsible for wholesome and unwholesome effects of the Ahara and methods of Ahara sevana (special rule for diet intake). These eight dynamics must be measured before taking food Prakriti, Karana, Samyoga, Rashi, Desha, Kala, Upyoga-sansatha and Upyokta.

Viewing the above points, it can be concluded that Ahara should be taken according to these eating habits are mentioned by Acharyas in the form of Ashta Ahara Vidhi Visheshayatana which has been proven very scientific. So, by following these habits, we can prevent ourselves from various health problems and can cure many other diseases.

\section{CONCLUSION}

Ahara isn't only needed for the continuity of life, but also Bala, Varna, Upacaya etc. In today's modern era, we are neglecting the digestive capacity nutritional value of food products, ready to eat food material. Lack of knowledge about correct eating habits is the primary region for the increasing trend of health disorders like diarrhoea, indigestion, hyperacidity, and anorexia etc. So, for preventing these disorders, the best way is to understand Ahara Vidhi Visheshayatana explains the various dietary habits. It helps to know about choosing appropriate food, a combination of food, cooking method, quality, and quantity of food.

Ahara Vidhi Visheshayatana is one of the most beneficial for achieving the noble goal of maintaining health. By proper understanding and following these, we can easily achieve both the Prayojana of Ayurve$d a$. Therefore, there's a requirement to illuminate this concept of Ahara Vidhi Visheshayatana as described in ancient Ayurveda classics.

\section{REFERENCES}

1. A textbook of Ayurvediya Physiology- Prof. Dr Yogesh Chandra Mishra, Chaukhambha Publication, edition 2018, chapter 11, vol 1 p no. 276 -277.

2. Sushruta Samhita Vol. 2, Chaukhambha Sanskrit Prakashan - Varanasi 2007, Chikitsasthana chapter 24/68, page no. 384.

3. Charak Samhita vol. 1, editor - translator - Prof. Priyavrat Sharma, Chaukhambha Orientalia - Varanasi 2004, Sutrasthana chapter 27/349-350, page no. 225.

4. Charak Samhita vol. 2, Chaukhambha Orientalia Varanasi 2008, Sutrasthana Chapter 28/45, page no.575.

5. Ashtangahridayakara, with the commentary Sarvasundar \& Ayurvedarasayana edited by Pt. Sadashivshastri Paradakara, published by Chaukhambha Sanskrit Samsthana, Varanasi 2009, Nidanasthana, chapter 12/1, page no. 513.

6. Kashyapa Samhita, Vridhajivakiya Tantra, editor translator- Prof. P.V. Tiwari, Chaukhambha Visvabharati 2016, Khalistan chapter 5/9, page no.485.

7. Charak Samhita vol. 1, editor - translator - Prof. Priyavrat Sharma, Chaukhambha Orientalia - Varanasi 2004, Vimana Sthan chapter 1/21, page no. 305.

8. Charak Samhita part 1, pt. Kashinath Sastri, Dr Gorakhanatha Chaturvedi, editor - Pt. Rajeshwar Dutta Sastri, Chaukhambha Bharti Academy Varanasi 2013, Vimansthana chapter 1-21/3-page no. 681.

9. Charak Samhita vol. 1, editor - translator - Prof. Priyavrat Sharma, Chaukhambha Orientalia - Varanasi 2004, Vimansthana chapter 1/21, page no. 305.

10. Agnivesha, Charak Samhita with Vidyotini Hindi Commentary of Pt. Kashinatha Sastri and Dr Goroka Natha Chaturvedi Ji, Chaukhambha Bharati Academy, Varanasi. Reprint year: 2005, Vimana Sthana Chapter 1 Verse 21/2.

11. Charak Samhita vol. 1, editor - translator - Prof. Priyavrat Sharma, Chaukhambha Orientalia - Varanasi 2004, Vimana than chapter 1-21/2, page no. 305.

12. Charak Samhita part 1, pt. Kashinath Sastri, Dr Gorakhanatha Chaturvedi, editor - Pt. Rajeshwar Dutta Sastri, Chaukhambha Bharti academy Varanasi 2013, Vimansthana chapter 1- 21/3-page no. 681.

13. Agnivesha, Charak Samhita with Vidyotini Hindi Commentary of Pt. Kashinatha Sastri and Dr Goroka Natha Chaturvedi Ji, Chaukhambha Bharati Academy, Varanasi. Reprint year: 2005, Vimana Sthana Chapter 1 Verse 21/4. 
14. Agnivesha, Charak Samhita with Vidyotini Hindi Commentary of Pt. Kashinatha Sastri and Dr Goroka Natha Chaturvedi Ji, Chaukhambha Bharati Academy, Varanasi. Reprint year: 2005, Sutra Sthana Chapter 5/ 3.

15. Ashtanga Hridayam of Vagbhata, commentary by Dr Bulusu Sitaram, published by Chaukhambha Orientalia Varanasi 2008, sutrasthana 8/46-page no.123.

16. Agnivesha, Charak Samhita with Vidyotini Hindi Commentary of Pt. Kashinatha Sastri and Dr Goroka Natha Chaturvedi Ji, Chaukhambha Bharati Academy, Varanasi. Reprint year: 2005, Sutra Sthana Chapter 5/ 6-7.

17. Agnivesha, Charak Samhita with Vidyotini Hindi Commentary of Pt. Kashinatha Sastri and Dr Goroka Natha Chaturvedi Ji, Chaukhambha Bharati Academy, Varanasi. Reprint year: 2005, Vimana Sthana Chapter $2 / 7$.

18. Charak Samhita vol. 1, editor - translator - Prof. Priyavrat Sharma, Chaukhambha Orientalia - Varanasi 2004, Vimansthana chapter 1-21/4, page no. 305,306.

19. Ch.Vi.1/21-6 Agnivesha, Charak Samhita with Vidyotini Hindi Commentary of Pt. Kashinatha Sastri and Dr Goroka Natha Chaturvedi Ji, Chaukhambha Bharati Academy, Varanasi. Reprint year: 2005, Vimana Sthana Chapter 1 Verse 21-6

20. Kashyapa Samhita, Vridhajivakiya Tantra, editor translator- Prof. P.V. Tiwari, Chaukhambha Visvabharati 2016, Khalistan chapter 5/11, page no.485.

21. Charak Samhita vol. 1, editor - translator - Prof. Priyavrat Sharma, Chaukhambha Orientalia - Varanasi 2004, Vimansthana chapter 1-21/6, page no. 306.

22. Agnivesha, Charak Samhita with Vidyotini Hindi Commentary of Pt. Kashinatha Sastri and Dr Goroka Natha Chaturvedi Ji, Chaukhambha Bharati Academy, Varanasi. Reprint year: 2005, Vimana Sthana Chapter 1 Verse 21-8.

\section{Source of Support: Nil \\ Conflict of Interest: None Declared}

How to cite this URL: Namrata Sahu et al: An Ayurvedic Review On Ashta Ahara Vidhi Vishesh Ayatana. International Ayurvedic Medical Journal \{online\} 2021 \{cited September 2021\} Available from: http://www.iamj.in/posts/images/upload/2155_2159.pdf 